\title{
A relação entre família, política e mulheres
}

\author{
Natália Cristina Granato ${ }^{1}$
}

A relação entre família e política é um importante eixo de estudo para a compreensão do poder nas sociedades contemporâneas, ocidentais e orientais. Este número da presente revista demonstra aos leitores a abrangência global do fenômeno, analisado nas pesquisas empíricas comparativas entre a Europa, ou mais especificamente a França, remetendo-se ao continente Asiático (em países como Índia, Paquistão e Líbano) e africano (Senegal, Marrocos e Quênia).

O artigo a seguir, intitulado "Quando as mulheres herdam: uma análise de gênero dos fenômenos de linhagens na Ásia Meridional”, de Virginie Dutoya², debruça-se sobre a relação entre família e política, incluindo a variável gênero no estudo da mesma. Pesquisadora do CNRS (Centre National de la Recherche Scientifique), o maior órgão público de pesquisa na França, faz parte do corpo de pesquisadores do Centro Émile Durkheim, da Universidade de Bordeaux, que analisam seus objetos de estudo sob perspectiva comparada. Algumas destas pesquisas estão presentes nesta coletânea de artigos, muitos partindo do distrito de Gironda, onde se localiza a cidade e a Universidade de Bordeaux, para as comparações com outros continentes e localidades. As pesquisas de Dutoya centram-se nos estudos de gênero, representação política e feminismo. No caso do artigo, sua análise refere-se aos casos da Índia e do Paquistão.

O foco do artigo é a análise da reprodução das representações e hierarquias de gênero, que se constituem como formas de acesso ao poder político para as mulheres da Índia e do Paquistão. Tal fenômeno ocorre por via hereditária, demonstrado nos dados qualitativos e quantitativos a respeito das mulheres parlamentares desde 1947. Isto é oposto aos princípios

\footnotetext{
${ }^{1}$ Doutoranda em Sociologia pela Universidade Federal do Paraná (UFPR). Pesquisadora do Núcleo de Estudos Paranaenses (NEPUFPR). Mestra em Sociologia, Bacharela e Licenciada em Ciências Sociais pela Universidade Federal do Paraná. Endereço eletrônico: nataliagranato@hotmail.com

2 Texto original "Quand les femmes héritent: une analyse genrée des phénomènes lignagers en Asie du Sud», Critique internationale, vol. 73, no. 4, 2016, p. 19-36. Disponível em https://www.cairn.info/revue-critique-internationale-2016-4-page19.htm. Acesso 25.outubro.2017.
} 
democráticos e igualitários que preveem um sistema eleitoral aberto e competitivo. A sucessão por via familiar reserva aos herdeiros o acúmulo de posições elevadas em detrimento daqueles que não possuem heranças políticas familiares. A autora sustenta que esta transmissão privilegia os homens para a ocupação de esferas de poder, e mesmo quando as mulheres ocupam tais espaços, estas são controladas pela lógica da estrutura patriarcal, pois recorrentemente devem seus cargos aos seus pais ou aos seus maridos.

Um dos pilares nos quais se sustentam as desigualdades de gênero na política baseia-se na separação entre a esfera pública e política, reservada aos homens nas democracias liberais, da esfera privada e doméstica, na qual situam-se as mulheres, supostamente incapazes ao exercício da cidadania com imparcialidade e controle dos afetos. Sob a perspectiva de gênero, a autora parte da premissa de que a família é uma instituição "marcada pelo poder e pelas desigualdades". Sabendo-se desta premissa, as principais perguntas do trabalho são: "existem contextos familiares e políticos que são estruturalmente mais favoráveis às mulheres?" e "em que medida a família constitui um recurso para as mulheres e qual é o custo desse recurso"? Para respondê-las, a autora adotou o princípio metodológico dos tipos ideais para analisar as redes de parentesco de aproximadamente 450 parlamentares eleitos entre 1947 e 2014 na Índia, cruzando tais dados com entrevistas realizadas com políticos indianos, mesclando técnicas quantitativas e qualitativas de análise.

A primeira parte do artigo dedica-se ao estudo do papel da família no sistema político indiano e o lugar das mulheres. A autora define parentesco através da linhagem comum, obtida por nascimento, adoção ou casamento. A noção de família política refere-se à transmissão do poder político para os herdeiros por via familiar. O fenômeno da hereditariedade familiar é um paradigma explicativo do fato de mulheres exercerem o cargo de primeiras-ministras no Estado indiano a partir de 1966 e paquistanês a partir de 1988, sendo as mesmas, segundo a autora, reprodutoras de práticas arcaicas, patrimoniais e pouco institucionalizadas. Os estudos citados por Dutoya indicam que as mulheres constituem a minoria dos herdeiros, mas a maioria das mulheres parlamentares são herdeiras políticas.

A segunda parte analisa as configurações familiares herdadas pelas mulheres na Índia. Para a autora, a conjugalidade é mobilizada de diferentes maneiras por homens e mulheres. Os dados indicam que poucos maridos herdam capitais políticos diretamente de suas esposas, mas sim da 
família de suas esposas, herdando capitais dos sogros, por exemplo. Em contrapartida, muitas mulheres herdam capitais diretamente dos seus maridos, mas muito raramente da família dos seus maridos ou dos seus sogros. Outra constatação se refere ao fato das mulheres também transmitirem capitais políticos para os seus filhos. Um dado importante é o de que a transmissão de capitais políticos pelas famílias políticas através da filiação difere entre os homens e mulheres. Com maior recorrência do que os homens, as herdeiras de capitais paternos são solteiras. Os dados indicam que prioriza-se a transmissão de capitais políticos para os homens. Quando as mulheres herdam, elas automaticamente devem seus cargos às suas famílias, devendo prestar contas às mesmas com mais precisão.

Nas considerações finais, a autora debruça-se sobre a "ambivalência do recurso familiar para as mulheres". Dada a constatação de que a vida política do sul da Ásia é majoritariamente masculina, o fato de uma mulher ser herdeira deve-se muitas vezes à reprodução de estereótipos de gênero, na qual a mesma foi escolhida por ter uma imagem de recatada, dócil, sem uma individualidade definida ou ambições pessoais, o que a tornaria uma legítima representante do legado familiar. Tendo em vista a segregação entre os sexos nestes países, uma herdeira é plausível dada a sua maior capacidade de aproximação com as eleitoras, diferente dos homens.

Dutoya assinala as restrições vivenciadas pelas mulheres na política, apontando, porém, para possibilidades de atuação não passiva das mesmas no jogo de disputas familiares e partidárias, o que pode ser aprofundado depois da aprovação da lei que disponibiliza reserva de vagas para mulheres no parlamento por meio de cotas. No entanto, o que se verifica é a recorrência de maridos que governam através de suas esposas e a manutenção de lógicas patriarcais.

A autora aponta para a crítica a dinastias políticas ocupadas pelos homens, que deve ser aprofundada nos debates de gênero, quando tal transmissão de privilégios prejudica também a autonomia enquanto pessoa eleita, sentida pelas mulheres. Como discussão de amplo alcance, Dutoya defende que "a transmissão do poder político pela família questiona a autonomia do campo político", criticando tal prática reproduzida por homens e mulheres na Ásia Meridional.

Este artigo é um primoroso exemplo de mobilização dos conceitos de gênero e poder, relacionados ao conceito de família, categoria fundamental para a apreensão da lógica de reprodução das desigualdades sociais e políticas. Tal crítica, profundamente necessária na 
investigação sobre as sociedades contemporâneas, vêm sendo empiricamente desenvolvida nas pesquisas presentes nesta coletânea. A difusão global deste tipo de análise é recomendável e promissora para as Ciências Sociais. 